\title{
Developing a Seasonal Cash Demand Simulation for Agricultural Cooperatives (Village Unit Cooperative) in Indonesia
}

\author{
Budi Santoso \\ Program Magister Manajemen, Universitas Mataram, Indonesia
}

\begin{abstract}
Irrespective of the success of the Indonesian Government to achieve self-sufficiency of rice in 1985, and the rice price stabilization, paddy growers still suffer from a very low price for their produce. Koperasi Unit Desa (KUDs) -in Indonesian, or Village Unit Cooperative (VUC) have been entrusted with the marketing of rice paddies although their performance has always been less than satisfactory. One problem experienced by the KUDs is not having sufficient cash to purchase and process paddies into rice. The purpose of this study is to develop and validate a simulation model to represent cash flows during one paddy plantation season for a KUD (VUC). The simulation model is a decision support tool that enables a KUD's (VUC) management to determine the maximum quantity of paddies to be purchased; the minimum borrowing and additional borrowing; and the earnings before taxes. An investigator-administrated questionnaire was used to collect historical data of the twenty randomly selected KUDs (VUC) on Lombok Island to validate the sub-models of the simulation model. The KolmogorovSmirnov Goodness of Fit (two-sample), linear regression, correlation and t- tests were used to validate the simulation model. The validation results have shown that the sub-models of the simulation model are valid, and these may contribute to the valid results of the simulation model. This study has found that the limitations of the paddy storage building, drying floor, and milling machine owned by the KUDs (VUC) may restrict the KUDs (VUC) from buying the entire paddies harvested. Therefore, further research is needed to find out the minimum capacities of those facilities enabling the KUDs (VUC) to work efficiently.
\end{abstract}

\begin{abstract}
Abstrak: Dibalik keberhasilan yang telah dicapai Pemerintah Indonesia dalam swasembada pangan/ beras pada tahun 1985, dan stabilisasi harga beras, petani padi masih menderita akibat sangat murahnya harga hasil produksinya. Koperasi Unit Desa (KUD) yang telah dipercaya berfungsi pemasaran gabah/ beras padahal kinerjanya selalu menunjukan sangat buruk. Satu kendala yang dialami oleh KUD adalah tidak memiliki cukup dan untuk membeli gabah dan memprosesnya menjadi beras. Tujuan penelitian ini adalah mengembangkan dan mem-validasi simulasi aliran kas dalam satu musim tanam padi untuk KUD. Simulasi ini merupakan suatu alat bantu pengambilan keputusan yang memungkinkan pengelola KUD untuk menentukan: jumlah maksimal gabah yang bisa dibeli; pinjaman minimum dan pinjaman tambahan; dan laba sebelum pajak. Daftar pertanyaan dimanfaatkan untuk mengumpulkan data dari dua puluh KUD di pulau Lombok yang dipilih secara acak untuk mem-validasi sub sistem simulasi. Kolmogorov-
\end{abstract}

Corresponding authors. E-mail: hebato@yahoo.com

ISSN: $1141-1128$

http://www.gamaijb.mmugm.ac.id/ 
Smirnov Goodness of Fit, regresi linear, uji korelasi dan t-test dipergunakan untuk mem-validasi simulasi. Hasil validasi menunjukan bahwa sub-sistem simulasi valid, dan ini bisa berkontribusi terhadap validitas hasil simulasi secara keseluruhan. Dari hasil kajian ini, didapatkan pula bahwa keterbatasan kapasitas gudang, lantai jemur dan mesin giling yang dimiliki oleh KUD yang membatasinya untuk mampu membeli seluruh hasil panen petani padi di wilayahnya. Untuk itu, penelitian lanjutan diharapkan untuk dapat mengidentifikasi kapasitas yang sekurang-kurangnya dimiliki oleh KUD untuk bisa bekerja secara efisien.

Keywords: agricultural cooperatives (Village Unit Cooperative); seasonal demands; cash flows; simulation; validation 


\section{Introduction}

Indonesia is commonly described as a Developing Country and about 58 percent of its population lives in rural areas (World Bank 1998a). In 1997, (the year for which the most recent figures are available) the total population of Indonesia (the fourth-populous country in the world) is approximately $200.1 \mathrm{mil}-$ lion people (World Bank 1998a). This means that approximately 116.06 million people live in rural areas. Generally, these areas are characterized by a traditional agricultural-based life style.

From an economic point of view, compared to other sectors, the agricultural sector has made the smallest total contribution to Indonesia's Gross Domestic Product (GDP). At the end of the sixth five-year development era (1996/1997), agriculture accounted for approximately 16.1 percent of Indonesian GDP, other sectors such as industrial sectors contributed approximately 43.9 percent, and service sectors approximately 40.1 percent (World Bank 1998a). Regardless of its small contribution to the Indonesian GDP, the agricultural sector has been the largest employer of people who live mainly in rural areas. According to the World Bank (1998b), Indonesian people in employment number 91 million, of whom about 50.96 million (56\%) worked in the agricultural sector (see also Ferry 1988). The service sector, which is the second largest area of employment, employed about 28.21 million (31\%) people (World Bank 1998b). The industrial sector employed approximately 11.83 million (13\%) people (World Bank 1998b). Thus, the agricultural sector has a very important role in Indonesia's economy (Dillon 1992). Moreover, the most recent reports have revealed that the agricultural sector isa dominant alternative employment for people who have lost their jobs because of the economic crisis in Indonesia since late 1997 (IMF 1998; Pambudy 1998c; YAS 1998).

In 1996, approximately 51,101,506 tons of paddies were produced nationally (Biro Pusat Statistik 1999)1. This produce is equivalent to about $28,616,843.36$ tons of rice (assuming that the conversion rate is $56 \%$ ). Meanwhile, the national rice consumption per year is about 29,400,000 tons of rice (equivalent to 52,500,000 tons of paddies). This number is based on an average rice intake per person per year of 147 kilograms. Again, from an economic viewpoint, there was an excess demand of paddies/rice. Theoretically, the excess demand should increase the price of paddies/rice. In fact, every time a paddy harvest season comes, paddy growers have to sell their produce at a lower price than the floor price set annually by the Indonesian Government (Suyanto 1996; Harijono 1998; Suganda 1998; SAH. et al. 1999).

Agricultural cooperatives (Indonesian: Koperasi Unit Desa or KUD) were introduced and established in 1973, and they have been entrusted with the marketing of paddies. A KUD may cover an area as small as one village. Based on the most recent data available released by the Indonesian Board of Statistics (1993), about 8,679 KUDs operate in Indonesian villages. The main duties of KUDs are to ensure their members (farmers) get agricultural inputs with a relatively stable price, and sell produce with a price as low as the floor price. The similar function of an agricultural cooperative was also found in the

${ }^{1}$ Cited from Biro Pusat Statistik [Central Bureau of Statistics] homepage: http://www.bps.go.id/statbysector/ agri/pangan/table1.shtml. 
U.S.A. (Oehler 1996; Knoeber 1997; Demetrakakes 1998), in India (Kumar 1990; Sidhu and Sidhu 1990), in Malaysia (Ramli 1988), in Thailand (Boonma 1988), in Korea (Kim 1988; Lee 1988), in Taiwan (Chen 1988), in Japan (Fukui and Hirose 1993), Nicaragua (Kroeke 1996), and in Australia (Langdon 1991; Langdon 1994). However, up to now, KUDs have been blamed for letting paddy growers suffer from a very low price for their produce. Paddy growers often have had to sell their produce at a price lower than the floor price. Reports of the Indonesian media and findings of recent researchers have suggested that several factors may contribute to the unsatisfactory performance of KUDs. First, although the Indonesian Government provides a low interest rate for loans, KUDs are still unable to purchase continuously their members' produce because of an apparent cash shortage (P3P 1997; Santoso 1993). This implies that whenever KUDs did not purchase their members' produce the members (paddy growers) had to sell their produce to private paddy wholesalers at a price lower than the price paid by KUDs. Second, a lack of transport facilities may also contribute to the inability of KUDs to purchase paddies directly from paddy growers, and on the other hand, farmers do not have enough funds to transport their produce to KUD locations (Santoso 1993; P3P 1997).

The KUD is an intermediary organization of the Indonesian Government to help and improve the welfare of farmers (paddy growers), and to stabilize the price of rice (Timmer 1996). The rationale of setting a floor price annually for farmers' produce is to help farmers get an income to support the minimum needs of their families. Timmer (1996, 1997), and Jones (1995) have stated that the stable food price (rice) may contrib- ute to the economic growth for developing countries.

However, up to now, there have been no serious attempts taken by the Indonesian Government or any other institution to solve the low paddy price that was routinely experienced by the paddy growers. Previous studies have only covered the prescriptive aspects of phenomena surrounding this problem. Pambudy (1998b), Ida (1996), and Krisnamurthi (1996) have argued that corruption, bureaucracy and a lack of managerial skills contribute to the unsatisfactory performance of KUDs. However, these studies have not given constructive and practical approaches to solve the problem.

\section{Objectives}

This study attempts to develop a simulation model to represent cash flows during a paddy plantation season for a KUD. The simulation model takes into account capacities of resources (paddies/rice storage building, paddy drying floor and paddy milling machine) owned by a KUD, and transport facilities (truck and other traditional means) that are available in the KUD location. Also, the simulation model can be used, as a decision support tool by management of a KUD to make a decision regarding the amount of cash required to provide agricultural inputs and to buy paddies, and to determine a quantity of paddies, which can be purchased on the basis of various scenarios. Therefore, the main purposes of this study are to develop a simulation model representing cash flows for a KUD during a paddy plantation season by taking into consideration the transport cost for transporting paddies from paddy fields to a KUD's location, to validate the simulation model, and to analyze the outputs of the simulation model. 


\section{Literature Review}

Before commencing the discussion of cash management models, it is necessary to cite three classical motives for holding cash. (Keynes, cited in Homonoff and Mullins 1975: 3)

".... the transaction motive relates to "holding cash to bridge the interval between the receipt of income and its disbursement [or] between the time incurring business costs and that of the receipt of the sale-proceeds." The precautionary motive concerns holding cash to provide "for contingencies requiring sudden expenditure and for unforeseen opportunities of advantage purchases." The speculative motive involves holding cash in order to secure "profit from knowing better than the market what the future will bring forth"; in other words, this motive is a function of expectations. Keynes believed the transactions motive and the precautionary motive to be essentially functions of the level of income (i.e., the money value of the transactions) and the speculative motive to be a function of the interest rate."

As far as this study is concerned, demand for cash is to fund the operating processes of a KUD during the paddy plantation season. This involves the first two motives, the transaction motive and the precautionary motive. The last motive, speculative motive, is not relevant to the nature of the cash flow model in this study. Holding cash in this study is not a function of the interest rate, because the interest rate of credit provided by the Indonesian Government for KUD and the interest rate of credit lent by KUD to its members (for agricultural credit program/KUT) is the same.

Cash management models discussed in the prior literature focus mainly on optimizing the cash balance, speeding or delaying specific cash flow components, and short run investment strategies. Among these works, is that of Baumol (1952) who applied an inventory modeling approach. He employed a deterministic model that assumes cash disbursements are spread over time, and cash receipts occur periodically at discrete points in time. His suggested model concentrates on the quantity and spending of funds transferred between transaction and investment accounts. In his model, Baumol assumed that to ensure a positive cash balance, a firm constantly and continuously reserves its cash balance by converting its asset to cash. Unlike Keynes, Baumol perceived that the transaction cash demand was a function of both income and interest rate (the combination of Keynes's three motives).

Another researcher, Tobin (1956) argued that the only motive for cash demand would depend inversely on the interest rate. Similar to Baumol, Tobin also employed a deterministic model, but he permitted the number of transactions into cash to take only positive integral values. He also assumed that (supporting Baumol's assumption as well) cash withdrawals should be evenly spread over time and in equal amounts.

In contrast to Baumol's deterministic model, Miller and Orr (1966) suggested an inventory modeling approach that assumes cash balances could be completely described by a stochastic generating process following a Gaussian function. Miller and Orr derived a control limit range (i.e., upper and lower bonds) for cash balances on the basis of interest rates, transaction costs, and an assumed stable cash flow probability distribution. For their modeling purpose, Miller and Orr assumed that there were only two assets of interest: cash and interest-bearing securities. The model incorporates the variance of daily cash balances into an expression for a firm's 
optimal cash balance level. They found that the transaction demand for cash is sensitive to income, interest rate and synchronization.

Neave (1970) examined the stochastic cash balance problem with fixed and proportional costs incurred whenever the inventory increases or decreases. The study focused on the positive transfer costs of the fixed component of stochastic cash balance. Neave employed convex upper and lower bounds on the cost functions partially to describe optimal policy. He argued that the convex bounding technique might provide an approach to study the complex optimal policy of inventory problems.

A more advance effort is that of Homonoff and Mullins (1975) who examined the assumption used in the model suggested by Miller and Orr in generating daily cash flow data. On the basis of extending the Miller-Orr model, they constructed and tested variations of an inventory control limit approach, though they saw the presence of systematic effects and sequential patterns, which violate the assumption underlying the Miller-Orr model. Although their models performed slightly better than those of previous models, they did not explore sophisticated approaches, which take into consideration dynamic properties of data.

Similar to Miller and Orr (1966), Constantinides (1976) suggested a continuous time model of cash management assuming stochastic demand, but allowing for positive and negative cash balances. He assumed fixed and proportional transaction costs. Unlike Neave, Constantinides assumed the optimal policy form was very simple.

Seeing cash management models as an inventory problem, Mensching et al. (1978) suggested the simple cash balance problem to determine the timing, direction and mag- nitude of transfers between a firm's earning asset and cash balance. They assumed that there would be a discrete-time, multi-period, and deterministic economic lot-size model allowing negative demands and disposal of goods. The heuristic procedures were used in a protective planning-horizon to determine the future demand of cash. The model considered the dynamic properties of data, but it did not take into account the stochastic demand of cash.

A more advance effort than that of Mensching et al. (1978), Chand and Morton (1982) developed a perfect planning horizon procedure for the simple deterministic cash balance problem assuming the requirements for cash (positive or negative) are known for several periods ahead. They stated that the model was guaranteed to obtain optimal initial decisions for the infinite horizon of cash balance problems by using the minimum possible number of periods of forecast data. They employed an efficient forward dynamic programming algorithm. Although their approach employed dynamic programming, they neglected the stochastic properties of daily cash flows.

A more recent study by Stone and Miller (1987) used multiplicative models of cash flow patterns for daily cash forecasting. They also underlined four common reasons contributing to the failure of most efforts at daily cash forecasting. First, the definition of major flows is not periodic and not generally estimable from past data. Second, the breakdown of non-major flows into components is sometimes neglected. Third, the requirement of information systems support to track hundreds of non-major cash flow streams as well as hundreds of individual non-major cash flow streams is ignored. Fourth, there is a failure to identify the pattern of daily cash flows. Stone and Miller employed log-linear 
models for treating day-of-week and day-ofmonth interaction of cash flow streams. Neither dynamic nor stochastic properties of daily cash flow data were included in their multiplicative models.

Another study, which considered cash balance problems, is Bergh and Hallerbach (1991) who suggested a simple model to solve one period stochastic cash problem assuming a fixed cash outlay at the end of the period. They also assumed the decision maker faces a single deterministic liability that is due at a certain time. A constant overdraft facility and the presence of an initial potential fund needed to be fulfilled in the model. Irrespective of the involvement of stochastic and dynamic properties of cash flow data, the model failed to fulfil the nature of stochastic cash outlay and the overdraft facility, which is stochastic in nature.

There have been a few attempts to study the efforts of improving cash management. Thompson (1986), and Madura (1987) revealed that simulation models could be used by decision makers to improve cash management. Moreover, Thompson (1986) stated that a computer simulation could provide an overview of the complex relationships within the business. A similar approach (a dynamicstochastic simulation model) was also suggested by Golub et al. (1995) to manage money for mortgage security.

Most prior researchers have attempted to study cash management models as a partial approach. One stream of researchers considered dynamic programming of cash management models, but neglected the stochastic properties of cash flow data. The other stream emphasized the stochastic properties of cash flow data on its cash management model, but overlooked the dynamic aspect of the model. Most prior researchers agreed that a simulation model might resolve the difficulties and complexities of the integrated approach of cash management models incorporating dynamic programming and stochastic properties of cash flow data.

There have been only a few studies which research cash management of agricultural cooperatives. Rasmussen (1983) underlined the difficulties of determining the proper level of cash to have on hand to meet liquidity and efficiency. Basset (1992) stated that the substantial margin of error has to be tolerantof forecasting cash to meet seasonal service demand.

Levy et al. (1989) examined the implications of financial cooperation in Israel's semi-cooperative villages. Their research focused on the problems associated with potential free ride when farmers' borrowings are uncoordinated. There are three main difficulties identified in their study. First, the usual pecuniary externality arose when cooperative members acted as price takers regarding the cost of credit, though the cooperative faced an upward sloping credit supply function. Second, the added uncertainty for the individual farmer stemmed from his dependence on the uncoordinated borrowing and investment behavior of other cooperative members. Third, the source of difficulties arose when cooperative members were heterogeneous in their production efficiency and attitudes to debt bearing. Their dynamic simulation results suggested debt-prone members of the cooperative would increase their debt position at the expense of debt-averse members. This finding undermined the stability of the co-operative. Based on theoretical considerations and empirical observations, each of these factors was worse during periods of general financial difficulty of farmers. However, the dynamic simulation used in the study did not 
taken into account stochastic properties of cash flow data.

Johnson and Crawford (1993) examined cash management in rural America. Their study described Basin Electric Power Cooperative's innovations in cash management. They underlined the main problem faced by the cooperative. At the same time that the cooperative needed to borrow funds to meet its seasonal cash requirements, its members invested their seasonal access liquidity in the same institution at a lower interest rate than that paid by the cooperative. The study described how the cooperative solved its problem by opening a new business section to accommodate its members' savings. However, the study did not include any dynamic and stochastic properties of cash flow data.

Zaman (1992) suggested a working capital management model for public enterprise in Bangladesh by strengthening the current ratio. He also identified that the working capital models suggested by Western scholars and the Indian Reserve Bank were not practically applicable under the environment constraints of Bangladesh. The results of that study indicated that the suggested prescriptive model improved the working capital position by gradually reducing the dependence on bank borrowings. However, the study did not consider stochastic and dynamic properties of cash flow processes.

Previous research has mainly focused on the role of the bank as an intermediary in the improvement of financing of rural small farms. This study attempts to fill the gap that is left by previous researchers. Hence this study will focus on the KUD as a financial intermediary to help peasant farmers in Indonesia have better access to credit. Most previous studies have given more attention to macroeconomic levels of rice price stabi- lization. In addition, the KUD that directly deals with farmers or producers was not a focus of the past studies. This study perceives the KUD as an important bridge between BULOG and farmers who need specific attention to obtain better income through gaining a reasonable price for their produce. The research efforts and methodologies reviewed in this chapter provide the foundations for the model developed in this thesis. The modeling approach provides a means for integrating the dynamic and stochastic properties of cash flow processes. This supplies the linkage between Baumol's deterministic assumptions and the purely stochastic proposition of Miller and Orr. The determinants investigated in this study include those identified in the agricultural cooperative cash management literature. The exponential family function (i.e., LogNormal) is mainly adopted to generate cash inflows and outflows associatedwith operating processes within a KUD during the paddy plantation season. Finally a simulation model is developed to represent integrated elements of the cash flow of a KUD during a paddy plantation season by incorporating a transport cost, and by considering resources and capacities owned by a KUD.

\section{Methods or Approaches}

This part will discuss short descriptions of the simulation model, how to build the simulation, how data are to be collected to run and validate the simulation model, and how to validate the simulation model.

\section{Why Use Simulation as the Research Method}

It has been stated that a computer simulation should be regarded as the last resort to be used to solve problems if all else fails (Pidd 
1993). This implies that building a computer simulation or program is surprisingly time consuming, and involves long computer programming of some complexity. However, since the purpose of this study is to develop a new cash flow model, which includes component costs (not existing in the current cash flow process), and complex processes, computer simulation may be the only way to cope with these phenomena. In general, there are two main reasons why a computer simulation should be used as a research method. These reasons are to overcome problems associated with real experimentation, and as an alternative to a mathematical model.

\section{Overcoming Problems of Real Experimentation}

Pidd (1993) has suggested four items that have to be considered to argue that a computer simulation can overcome problems associated with real experimentation. The first item is cost - building a computer simulation may be time consuming and expensive, however, real experiments might be more expensive if something goes wrong. The time taken to build a computer simulation is secondary. Although it would be time consuming and involvecomplex computer programming, once the computer simulation has been built, it can be used to simulate weeks or months or years in just a matter of seconds or minutes in computer time. The third item is replication. Under certain conditions, it would be impossible to repeat strategies or tactics or any other events using real experiments, due to high costs. However, a computer simulation can be replicated to achieve the expected results of a certain strategy or tactic. Finally, safety is the essential issue, which has to be considered, when real experimentation deals with extreme conditions. A computer simulation can cope with this requirement no matter how extreme the conditions are.

\section{An Alternative to Mathematical Modeling}

The suggested cash flow model is system dynamic, involving sequential processes and transient effects resulting from temporary impacts of rainfall, some capacities or constraints, and machine breakdowns. Mathematical models would not be able to cope with this process, and as a result, a computer simulation is the only way to tackle this process (Pidd 1993). In addition, mathematical models such as queuing theory may only permit a certain type of sample distribution, but on the other hand, a computer simulation may cope with any types of sample distributions (Pidd 1993).

\section{What is Borland Delphi?}

Borland Delphi for Microsoft Windows is a general purpose and relatively new native code compiler programming language that was first introduced in the first quarter 1995 by Borland International Corp. Borland Delphi enables application developers to build applications visually by dragging and dropping built-in and/or customized components onto a form, and linking/hooking them with minimum codes to respond to some event handlers. Borland Delphi is based on Object-Oriented Programming (OOP) architecture, Object Pascal. The Object Pascal is also called a bybrid language (Wozniewicz et al. 1995). This means that not only does it support an OOP approach to programming, but it also enables programmers to write nonobject oriented programs in a traditional, structured fashion. According to Calvert (1995), besides its capability to write/build 
one single executable program (without any additional files, except when Borland Database Engine is used) or library (dynamic link library) that runs on Microsoft Windows, Borland Delphi is very easy to learn, and as result, the learning curve is relatively short, usually less than one year. Thus, Borland Delphi can be defined as a visual, object-oriented, and components-based development environment (Pacheco and Teixeira 1995: 4).

Up to 1997, Borland International Corp. had released three versions of its Delphi family, namely: version 1.0, version 2.0, and version 3.0. Borland Delphi version 1.0 (hereinafter simply called: Borland Delphi) is hosted on Microsoft Windows 3.1 (hereinafter called: Windows 3.1) operating system, and is targeted to write 16-bit applications for Windows 3.1 or later. Of course, this does mean that 16-bit applications built by Borland Delphi can run on Microsoft Windows 95 (hereinafter called: Windows 95) or later and Microsoft Windows NT 3.51 (Service Pack 5, hereinafter called: Windows NT 3.51) or later. Meanwhile, Borland Delphi version 2.0, Borland Delphi version 3.0, and beyond run on Windows 95 or later and Windows NT 3.51 or later, and are used to create 32-bit applications for Windows 95 or later, and Windows NT 3.51 or later (see GreenBerg 1996). In this thesis, Borland Delphi solely refers to version 1.0 because the simulation is written in Borland Delphi, and is intended at minimum to be able to run on Windows 3.1 or later.

Figure 1. Activities During Paddy Plantation Season and Cash Inflows and Outflows Associated with Each Activity - from a KUD's Point of View

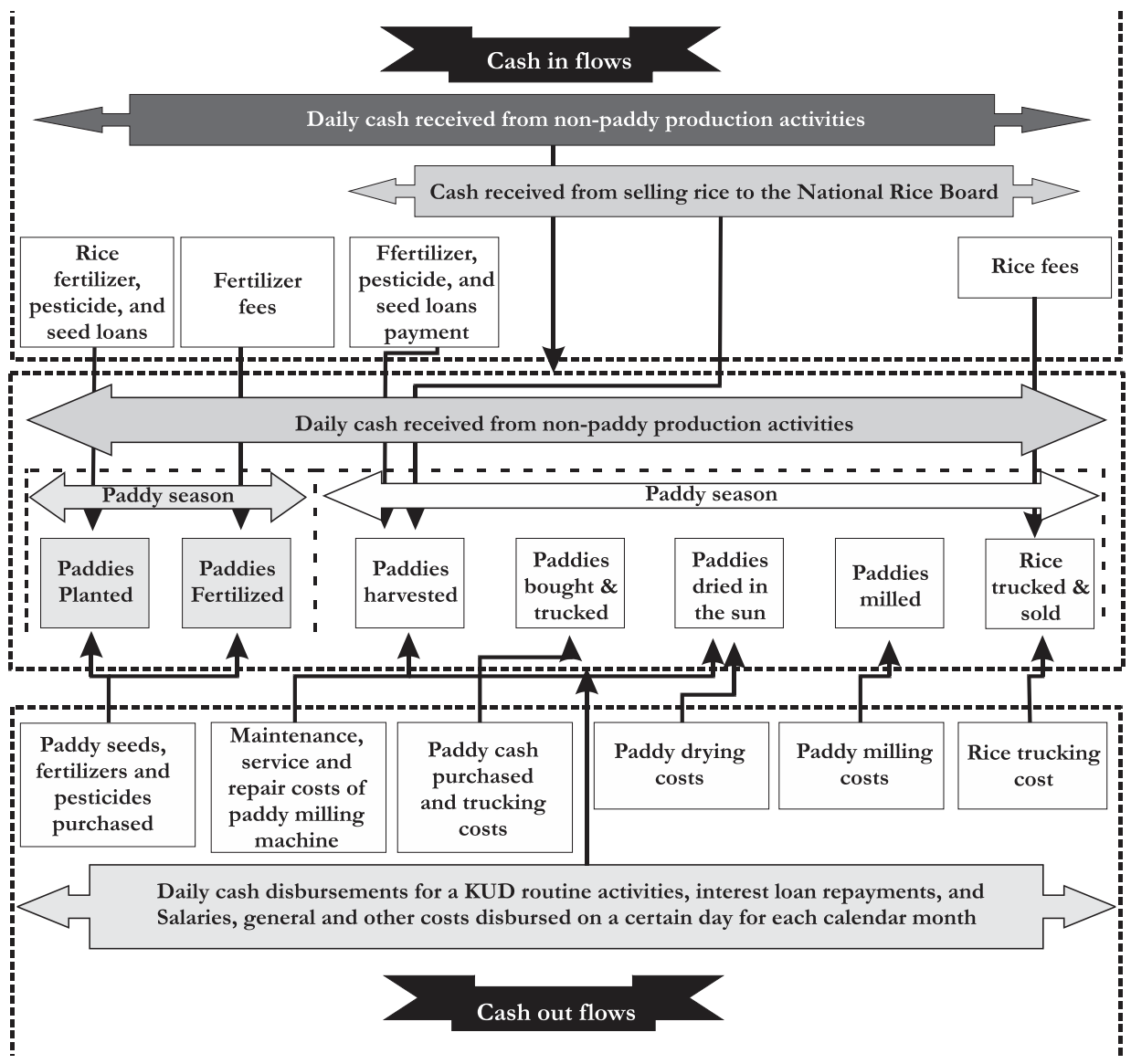




\section{The Simulation Models}

Mathematical model representations are used to visualize relationships of parameters and variables of real systems of cash flows of a KUD.

\section{Cash Flow Models}

This section will be divided into four main subsections. The first subsection will present and describe the model of cash inflows during the paddy season. The next subsection will introduce and outline the model of cash outflows of a KUD during the paddy season. Third, the model of cash inflows during the paddy harvest season will be presented. Finally, the discussion will be concluded by the introduction and description of the model used to calculate cash outflows during the paddy harvest season. The explanations can be seen clearly from Figure 1 above.

\section{Cash inflows during the paddy season}

During the paddy season, a KUD's cash inflows are mainly associated with the routine activities. The daily cash inflows may be generated from cash sales and repayment of credit sales of the mini supermarket owned by a KUD. Besides this source of cash, during this season a KUD may also receive loans from the People's Bank of Indonesia to provide paddy seeds, fertilizers, and pesticides. In addition, the bank may also provide loans (rice loans) to a KUD to purchase members' or farmers' paddies when the paddy harvest season is due. The fertilizer distributor may pay fees to a KUD resulting from fertilizer sold. Thus, the cumulative cash inflows on a certain day (day $t$ ) during paddy season can be represented in the following equation.

$$
\mathrm{PF}_{\mathrm{t}}^{\mathrm{ps}}=\sum_{\mathrm{t}}^{\mathrm{ps}}\left(\mathrm{C}_{\mathrm{j}}+\mathrm{CI}_{\mathrm{j}}+\mathrm{FL}_{\mathrm{j}}+\mathrm{RL}_{\mathrm{j}}+\mathrm{FF}_{\mathrm{j}}\right)
$$

where,

$$
\begin{aligned}
& \mathrm{t}=1,2, \ldots \ldots \ldots \ldots \ldots \ldots \ldots . . . \mathrm{n} \\
& \mathrm{n}=\text { Poisson }\left(\mathrm{PS}_{\mathrm{m}}\right)
\end{aligned}
$$

The cumulative cash inflows of a KUD on day $t\left(\mathrm{PF}_{\mathrm{t}}^{\mathrm{ps}}\right)$ during the paddy season (n) is the summation of available cash on hand at the beginning of that day $\left(\mathrm{C}_{\mathrm{j}}\right)$, daily or routine cash received from cash sales and repayments of credit sales of mini market commodities $\left(\mathrm{CI}_{\mathrm{i}}\right.$ ), agricultural input loans (fertilizer, pesticide and paddy seed loans) (FL), rice loan $\left(\mathrm{RL}_{\mathrm{j}}\right)$, and fertilizer fees $\left(\mathrm{FF}_{\mathrm{j}}\right)$. The length of the paddy season (n) or paddy age is a random number following a Poisson distribution [Poisson $\left(\mathrm{PS}_{\mathrm{m}}\right)$ ] given the mean $\left(\mathrm{PS}_{\mathrm{m}}\right)$ of a number of days of previous paddy seasons.

\section{Cash outflows during the paddy season}

As a formal organization, a KUD employs several people to handle daily operations. The people who work in a KUD include voluntary workers and paid workers. A manager, a secretary, a bookkeeper, some office workers, and an office guard are paid monthly. There are some other costs that are incurred monthly, associated with a KUD's routine operations such as general costs (electricity, telephone, water bills) and other monthly costs. Daily cash disbursement may also be incurred in a daily KUD's operation. There are also some cash disbursements to purchase paddy seeds, fertilizers, and pesticides. The cumulative cash outflows on day $t$ during the paddy season can be calculated by the following equation.

$$
\mathrm{PU}_{\mathrm{t}}^{\mathrm{ps}}=\sum_{\mathrm{j}=1}^{\mathrm{t}}\left(\mathrm{CO}_{\mathrm{j}}+\mathrm{FB}_{\mathrm{j}}+\mathrm{S}_{\mathrm{j}}+\mathrm{GC}_{\mathrm{j}}+\mathrm{OC}_{\mathrm{j}}\right)
$$

The cumulative cash outflows on day $t$, noted by $P U_{t}^{p s}$, is a total of daily cash dis- 
bursement $\left(\mathrm{CO}_{\mathrm{j}}\right)$, fertilizers, paddy seeds, pesticides and transport costs $\left(\mathrm{FB}_{\mathrm{j}}\right)$, salaries paid monthly $\left(\mathrm{S}_{\mathrm{j}}\right)$, general costs $\left(\mathrm{GC}_{\mathrm{j}}\right)$, and other costs $\left(\mathrm{OC}_{\mathrm{j}}\right)$.

\section{Cash inflows during the paddy harvest season}

Figure 1 shows that as well as cash received from daily operations (from the mini supermarket and other non-agricultural activities), from the first day of the paddy harvest season, a KUD will have additional cash inflows. These cash inflows may come from members' fertilizer credit payments, rice sold to DOLOG, rice bran sold to customers such as poultry, cattle and pig farmers, and rice fees paid by private paddy wholesalers who have used a KUD's stamp duty to sell their rice to DOLOG. The cumulative cash inflows on day $t$ during paddy harvest season can be seen in the following mathematical equation.

$$
\mathrm{PF}_{\mathrm{t}}^{\mathrm{ph}}=\sum_{\mathrm{j}=\mathrm{n}+1}^{\mathrm{t}}\left(\mathrm{C}_{\mathrm{j}}+\mathrm{RL}_{\mathrm{j}}+\mathrm{CI}_{\mathrm{j}}+\mathrm{RS}_{\mathrm{j}}+\mathrm{BS}_{\mathrm{j}}+\mathrm{FP}_{\mathrm{j}}+\mathrm{RF}_{\mathrm{j}}\right)
$$

where

$\mathrm{t}=\mathrm{n}+1, \mathrm{~N}+2, \ldots \ldots \ldots ., \mathrm{n}+\mathrm{k}$

$\mathrm{k}$ : the terminating day of the paddy plantation season is determined when all purchased paddies are dried, milled, and sold by a KUD

A KUD's cumulative cash inflow on day $t$ during paddy harvest season $\left(\mathrm{PF}_{t}^{\mathrm{ph}}\right)$ is a sum of the net cash flows carried forward from the paddy season $\left(\mathrm{C}_{\mathrm{j}}\right)$, rice loans $\left(\mathrm{RL}_{\mathrm{j}}\right)$, cash inflows from routine operations $\left(\mathrm{CI}_{\mathrm{i}}\right)$, cash received from rice sold to DOLOG $\left(\mathrm{RS}_{\mathrm{i}}\right)$, cash received from rice bran sold $\left(\mathrm{BS}_{\mathrm{j}}\right)$, cash received from fertilizer credit repayments (FP), and rice fees paid by the private paddy wholesalers $\left(R_{j}\right)$.

\section{Cash outflows during the paddy harvest season}

As well as routine daily and monthly cash disbursements incurred during the paddy season, there are also several cash outflows during the paddy harvest season. These additional costs are cash disbursements for buying and trucking paddies, drying paddies, and milling paddies. Cumulative cash outflows on day $t$ during the paddy harvest season can be modeled as follows:

$$
\mathrm{PU}_{t}^{\mathrm{ph}}=\sum_{j=\mathrm{n}+1}^{\mathrm{t}}\left(\begin{array}{l}
\mathrm{CO}_{\mathrm{i}}+\mathrm{S}_{\mathrm{i}}+\mathrm{GC}_{\mathrm{j}}+\mathrm{OC}_{\mathrm{j}}+\mathrm{PTCC}_{\mathrm{i}}+\mathrm{PBC}_{\mathrm{i}}^{+} \\
\mathrm{PDC}_{\mathrm{i}}+\mathrm{PMC}_{\mathrm{i}}+\mathrm{MSR}_{j}+\mathrm{RTCC}_{\mathrm{i}}+\mathrm{IP}_{\mathrm{i}}
\end{array}\right)
$$

The cumulative cash outflows on day $t$ during the paddy harvest season $\left(\mathrm{PU}_{\mathrm{t}}^{\mathrm{ps}}\right)$ is a sum of daily cash disbursed to fund routine activities $\left(\mathrm{CO}_{\mathrm{i}}\right)$, salaries $\left(\mathrm{S}_{\mathrm{j}}\right)$, general costs $\left(\mathrm{GC}_{\mathrm{j}}\right)$, other costs $\left(\mathrm{OC}_{\mathrm{j}}\right)$ monthly paid, paddy transport costs (PTCC), cash disbursed to buy paddies $\left(\mathrm{PBC}_{\mathrm{j}}\right)$, paddy drying costs (PDC $)$, paddy milling costs (PMC $)$, cash disbursed to service or repair the break down of paddy milling machines (MSR $)$, rice transport costs (RTCC $)$, and interest payments $\left(\mathrm{IP}_{\mathrm{j}}\right.$.

\section{How to Build the Simulation}

This section will explain the relationship of parameters and variables in the models previously discussed. The relationships of parameters and variables are translated into programming algorithms, and coded in Borland Delphi (as shown in Figure 2). Since this simulation model, enriched by a graphical user interface (GUI), will be built by using the general purpose programming language (Borland Delphi), several frequently used programming terms will be used during subsequent discussions. Delphi is an Integrated 
Development Environment (IDE) that enables a programmer to write (code), execute and debug applications without leaving the Delphi environment. Delphi comes with approximately 75 built-in components that are known as the Visual Component Library (VCL). These components are created by Delphi, and thus, they are native Object-Pascal compiled libraries. These VCLs enable applications to be distributed and executed/ run without any additional libraries or files. As mentioned earlier, in order to built a program or an application, a programmer has just to drop several components on a form (a basic skeleton of an application or a program), set appropriate properties of components at a design time or set properties programmatically at a run time, and link or glue them together to respond to event handler(s). As an analogy, to build a car, employees just have to assemble a car frame, machine, body, wheels, and interiors, to paint, test and run. The VCLs that come with Delphi are enough to build almost any type of application.

\section{Data to run and validate the simulation model}

Historical data used to run and validate the simulation results were collected using investigator-administrated questionnaires

Figure 2. Relationships between The Data Structure used to Hold Parameters and Variables, and Visual Interface of the Simulation Model

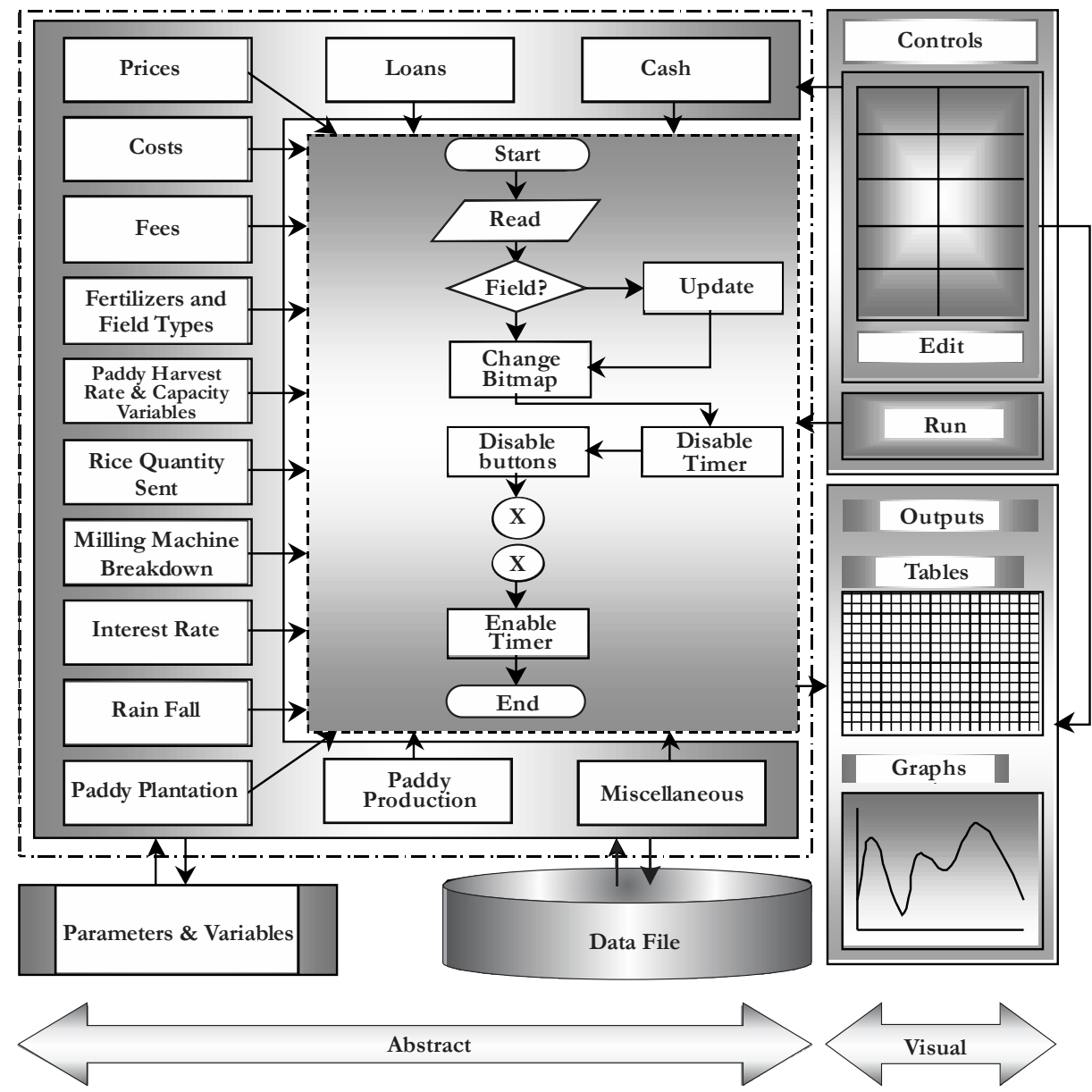


from twenty KUDs that were selected by using a stratified random sampling. Based on practicality, funds and time limit considerations, the sampled KUDs were among those located in Lombok Island. Two types of data were collected during the research, primary and secondary data.

The primary data includes: the amount of fertilizer, pesticide and paddy seed loan given by the Government; the cash balance at the beginning of paddy plantation season; the first date of paddies planted in a KUD location; the quantity and types of fertilizers, pesticides and paddies bought by a KUD; prices of fertilizer, pesticides, paddy seed, paddy, rice, and rice bran per unit; the number of members; paddy field areas owned by a KUD's members; the amount of rice loan lent by the Government; loan interest rate; lending interest rate; the number of paid workers; the amount of salaries, general costs, and other costs monthly paid; Paddies resulting from paddy fields owned by a KUD's member; paddy to rice conversion rate; paddy to rice bran conversion rate; daily cash received and disbursed respectively from and for businesses other than agricultural activities; storage, drying floors, milling machines, paddy and rice transport capacities; the days of fertilizer, pesticides and paddy seed loan, and rice loan liquidated; daily paddies directly bought from paddy fields by a KUD; drying and milling costs per unit paddies; fertilizer and rice fees; frequency of milling machine breakdowns; service and repair costs of milling machines; days of drying paddies; and frequency of monthly morning rain.
The secondary data includes: fertilizer, pesticide and paddy seed loan lent by each KUD in the region; the quantity of fertilizers, pesticides, and paddy seeds supplied by each KUD to its members; loan and lending interest rates; the quantity of paddies directly bought by each KUD from its members; and the quantity of rice sent and sold to DOLOG. From DOLOG, data may comprise of the quantity of rice bought from KUDs and nonKUDs; the price of rice; and the days of paying rice to the KUDs. Data gathered from the Department of Agriculture may include: the uses of each type of fertilizers and pesticides for wet and dry paddy fields; the age of several types of paddy varieties; paddy results from several types of paddy varieties per hectare of paddy field; paddy to rice and paddy to rice bran conversion rates; paddy field areas in each sampled KUD location; and places in which unsuccessful paddy seasons occurred, and the causes of the bad paddy season. Published or unpublished printed-materials from previous studies may provide qualitative data that are underlying assumptions, rules and other non-numeric data.

\section{How to validate the simulation model}

Several stochastic variables are used in the simulation model with assumptions following certain distributions. As such, the Kolmogorov-Smirnov Goodness Fit (TwoSample) Test $(D)$ was used to test the assumptions underlying the random generations of cash inflow and outflow streams, the general cost stream, the other cost stream, and the milling machine repair cost stream. The as- 
sumption is true (not rejected) if the calculated $D$ is less than the critical value of $D$ (Law and Kelton 1991). Since the final result of the actual system for each sampled KUD does not exist, the sub-models of the simulation model were compared against the sub-systems of the actual system (Law and Kelton 1991; Pidd 1993; Knepell and Arangno 1993; Paul and Balmer 1993; Kleijnen 1995a; Taber and Timpone 1996). The linear regression test (focusing on the intercept, the slope and the $R$ square), $t$-test and correlation test was used to validate those sub-models and sub-systems. The sub-models and the sub-systems that were validated are the quantity of paddies harvested daily, the frequency of monthly morning rain, and the amount of rice fees. The validations for each sampled KUD were conducted by 25, 50 and 100 replications with 95 percent of confidence levels respectively.

The sub-models' (modules') results, that can be validated, are the quantity of paddies harvested daily, the frequency of monthly morning rain, and the rice fees. The test used to validate these modules is linear regression, from which the fit between results of the subactual system and results of the sub-simulation model can be identified. The sub-simulation model is a complete resemblance of the sub- actual system under study if the intercept of the regression model is zero, the slope is one, and the R square is one (Cohen and Cyert 1961; Kleijnen and Groenendaal
1992; Kleijnen 1995a; Kleijnen 1995b). This requirement is too idealistic to achieve, so it is suggested that the sub-simulation model is still acceptable if there is strong evidence that the results of sub-simulation model and the results of sub- actual system are positively correlated (Kleijnen and Groenendaal 1992; Kleijnen 1995a; Kleijnen 1995b). The correlation tests are considered to be less stringent. A more rigorous requirement for determining the fit between the sub-simulation model and the sub-actual system is if the mean and variance of results of the sub-simulation model are equal to those of the subactual system (Kleijnen et al. 1998). The $t$ statistic ( $t$-test) will be used to identify the similarity of the mean and variance of the sub- simulation model' and sub- actual system' results. All these tests are based on the 95 percent confidence level.

\section{Results and Discussions}

In this article, only some results of the validation will be shown, and some of them can be seen as follow.

\section{Daily Cash Inflows and Outflows Test}

The summary of Kolmogorov- $D$ and $P$, and the $D$ critical table value based on significant levels of 1 percent, 5 percent and 10 percent can be seen in Figure 3 and Table 1. 
Figure 3. The List of Line Plots of the Sorted Actual Cash Flows and the Sorted Theoretical Cash Flows Generated by The Simulation Model for Each Sampled KUD

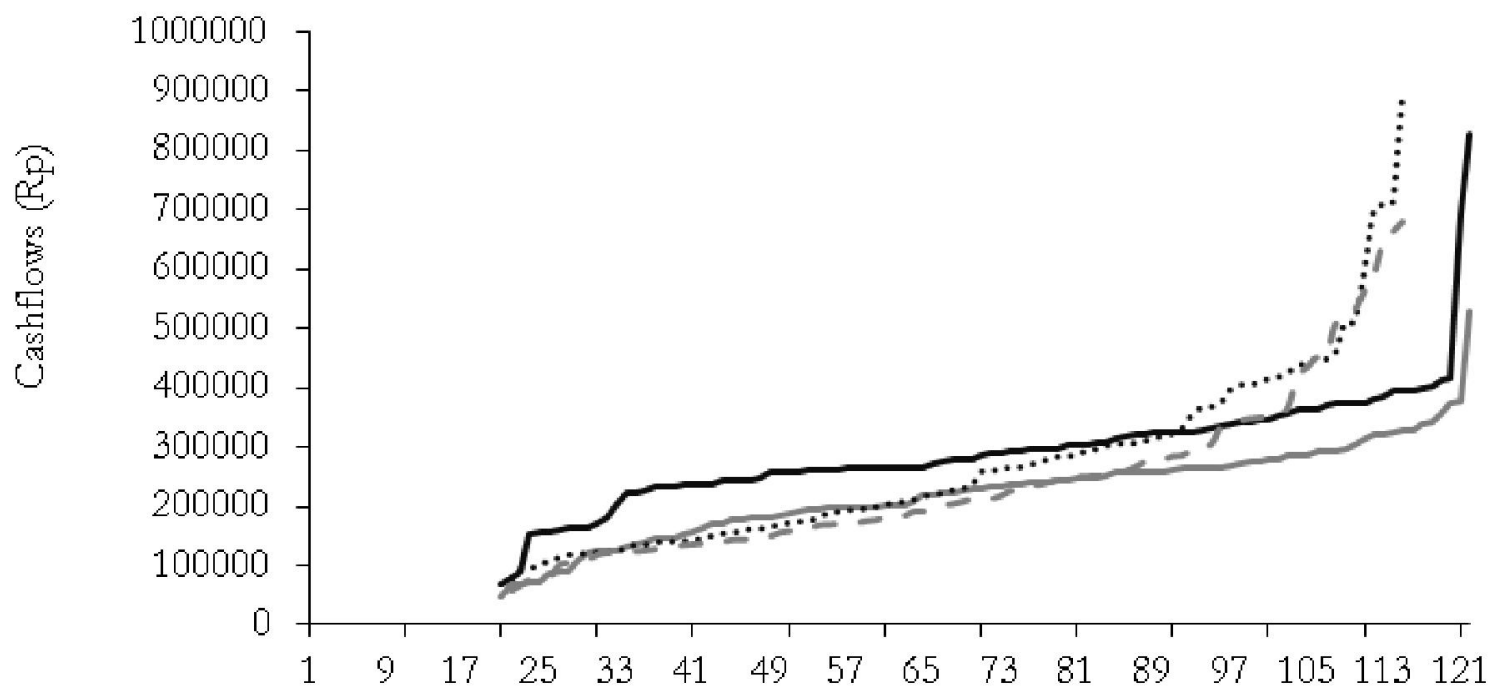

Sample 3

Time (Day)
- Observed Cash Inflows
Observed Cash Outflows
....... Predicted Cash Inflows
- Predicted Cash Outflows

Sample 4

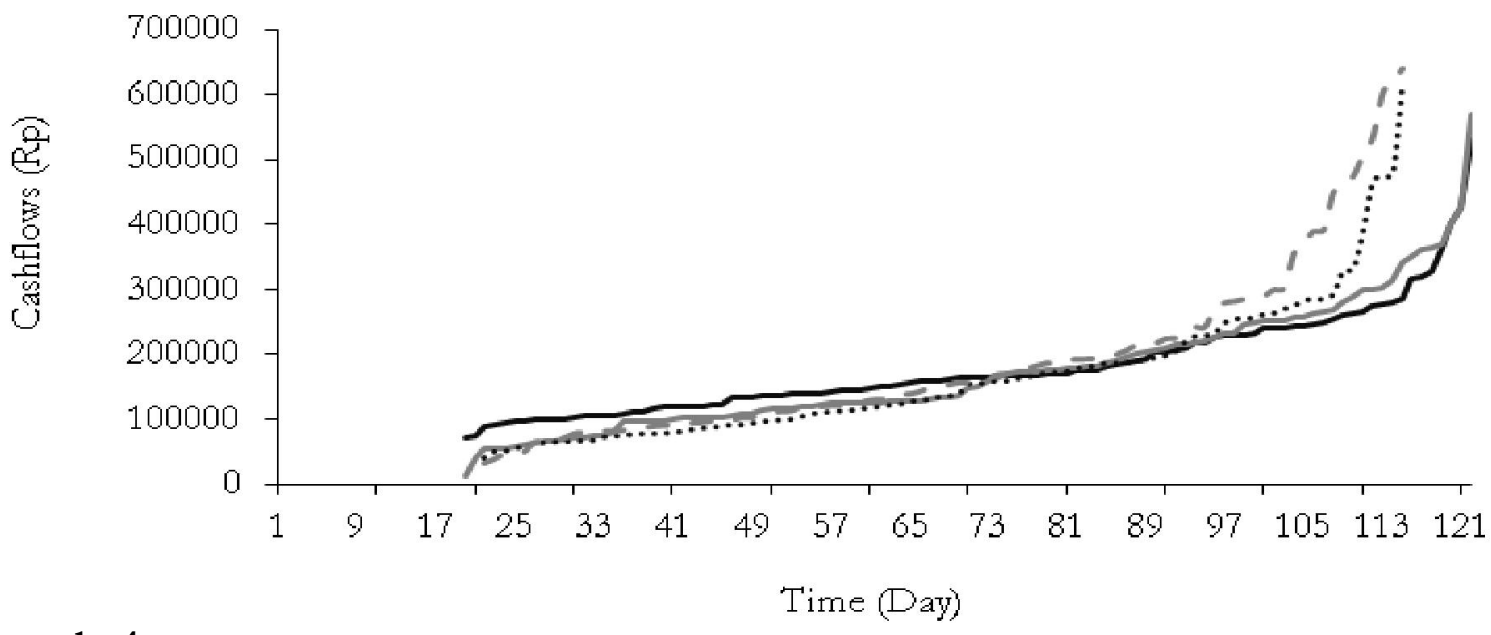

Observed Cash Inflows

- Observed Cash Outflows

Predicted Cash Inflows

- Fredicted Cash Outflows 


\section{Figure 3 (Continued)}

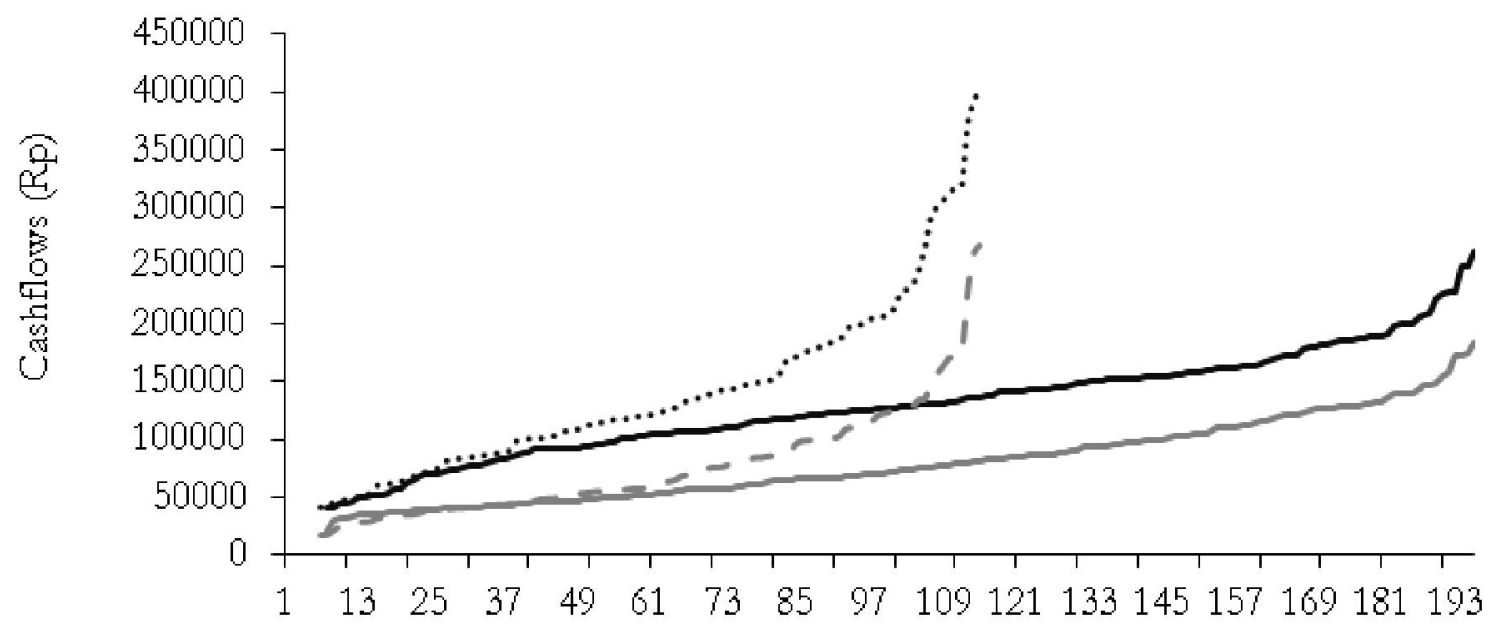

Sample 14

Time (Day)
- Observed Cash Inflows
- Observed Cash Outflows
....... Predicted Cash Inflows
- - Predicted Cash Outflows

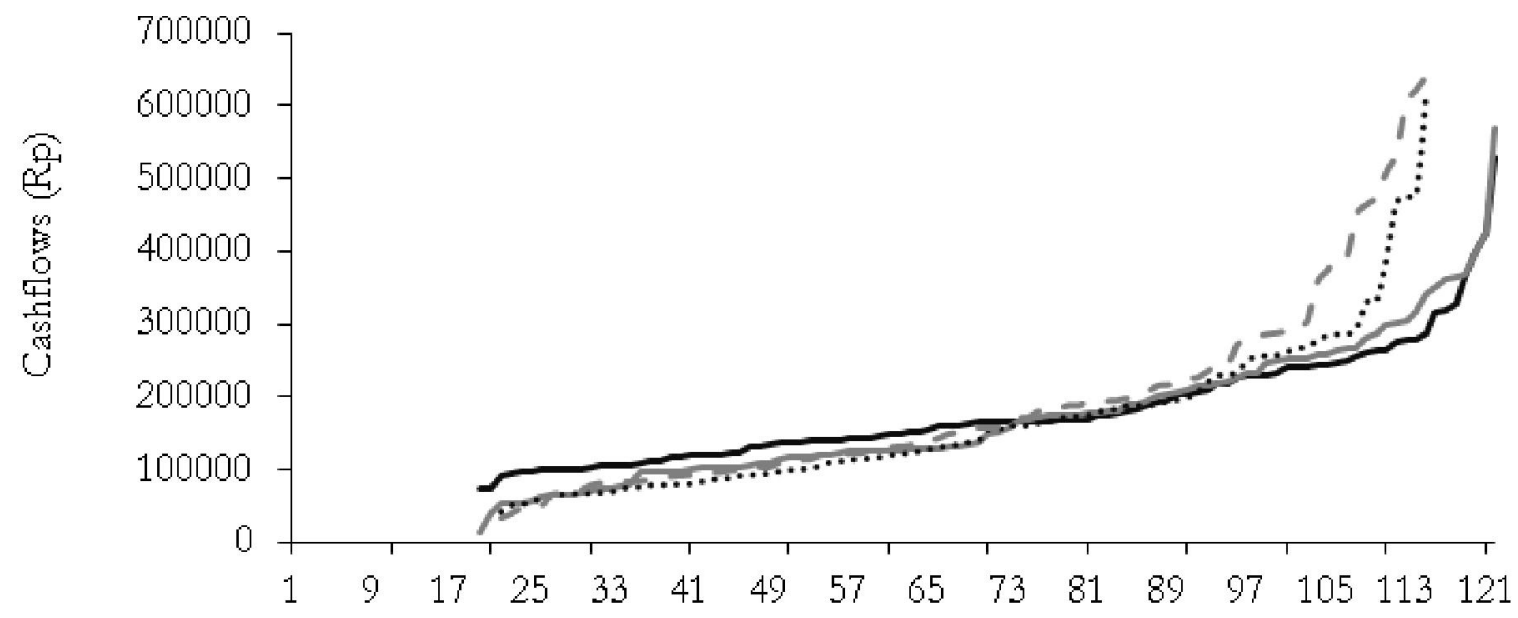

Sample 15

Time (Day)
- Observed Cash Inflows
Observed Cash Outflows
Predicted Cash Inflows
- - Predicted Cash Outflows 
Table 1. The Kolmogorov-Smirnov Goodness of Fit Test Results of Comparing The Actual Distribution Against The Theoretical Distribution of Cash Inflows and Outflows by Sampled KUD

\begin{tabular}{|c|c|c|c|c|c|c|c|}
\hline \multirow{2}{*}{$\begin{array}{c}\text { Sample } \\
\text { No }\end{array}$} & \multicolumn{2}{|c|}{ Cash Inflows } & \multicolumn{2}{|c|}{ Cash Outflows } & \multicolumn{3}{|c|}{ Critical Value of $D$} \\
\hline & $\mathbf{D}$ & $\mathbf{P}$ & $\mathbf{D}$ & $\mathbf{P}$ & $\alpha=0.01$ & $\alpha=0.05$ & $\alpha=0.1$ \\
\hline 1 & 0.137 & 1.000 & 0.202 & 0.966 & 0.209 & 0.195 & 0.157 \\
\hline 2 & 0.221 & 0.931 & 0.213 & 0.947 & 0.210 & 0.196 & 0.157 \\
\hline 3 & 0.292 & 0.680 & 0.144 & 1.000 & 0.209 & 0.195 & 0.157 \\
\hline 4 & 0.217 & 0.938 & 0.110 & 1.000 & 0.209 & 0.195 & 0.157 \\
\hline 5 & 0.225 & 0.918 & 0.192 & 0.979 & 0.209 & 0.195 & 0.157 \\
\hline 6 & 0.210 & 0.951 & 0.135 & 1.000 & 0.209 & 0.195 & 0.157 \\
\hline 7 & 0.302 & 0.645 & 0.286 & 0.710 & 0.210 & 0.196 & 0.158 \\
\hline 8 & 0.196 & 0.988 & 0.257 & 0.884 & 0.226 & 0.211 & 0.169 \\
\hline 9 & 0.308 & 0.497 & 0.173 & 0.982 & 0.191 & 0.178 & 0.143 \\
\hline 10 & 0.114 & 1.000 & 0.109 & 1.000 & 0.192 & 0.179 & 0.143 \\
\hline 11 & 0.242 & 0.868 & 0.184 & 0.987 & 0.209 & 0.195 & 0.157 \\
\hline 12 & 0.208 & 0.978 & 0.206 & 0.981 & 0.226 & 0.211 & 0.169 \\
\hline 13 & 0.113 & 1.000 & 0.096 & 1.000 & 0.210 & 0.196 & 0.157 \\
\hline 14 & 0.196 & 0.937 & 0.137 & 0.999 & 0.188 & 0.176 & 0.141 \\
\hline 15 & 0.291 & 0.549 & 0.246 & 0.752 & 0.188 & 0.175 & 0.141 \\
\hline 16 & 0.210 & 0.954 & 0.167 & 0.996 & 0.210 & 0.196 & 0.158 \\
\hline 17 & 0.181 & 0.967 & 0.262 & 0.679 & 0.188 & 0.175 & 0.141 \\
\hline 18 & 0.099 & 1.000 & 0.117 & 1.000 & 0.188 & 0.175 & 0.141 \\
\hline 19 & 0.238 & 0.788 & 0.216 & 0.874 & 0.188 & 0.175 & 0.141 \\
\hline 20 & 0.085 & 1.000 & 0.102 & 1.000 & 0.188 & 0.175 & 0.141 \\
\hline Mean & 0.204 & 0.879 & 0.178 & 0.937 & 0.203 & 0.189 & 0.152 \\
\hline SD & 0.067 & 0.159 & 0.058 & 0.103 & 0.013 & 0.012 & 0.010 \\
\hline
\end{tabular}


As seen from Table 1, on average the theoretical distribution ( $\log N$ ormal) of daily cash inflows and outflows, that was generated by the simulation model based on the given mean and standard deviation derived from historical data of 20 sampled KUDs, has a similar shape to the actual distribution. Based on the criteria discussed in Section 5.5.2, the theoretical distribution ( $\log N o r m a l)$ assumption used to generate the daily cash inflows does not fit the actual distribution. This is because the calculated $D(0.204)$ is not smaller than the critical value of $D(0.203)$ at the 99 percent significance level. The actual distribution of cash inflows of Sample 3 is more likely following a normal distribution because it has routine and relatively constant daily cash inflows from its non-agricultural activities such building materials, and poultry. Similarly, Sample 7 and 9 have routine and relatively constant daily cash inflows resulting from their handcraft businesses. In contrast, Sample 15 and 19 have irregular, unstable and small daily cash inflows because they do not have substantial non-agricultural businesses. Their non-agricultural businesses mainly provide salt for drying-fish processes in their location (close to dried-fish industries). Also there is a large difference between the mean calculated $D$ and the mean critical $D$ at both 5 percent and 10 percent significant levels. Although the mean calculated $D$ of daily cash inflows is greater than its mean critical $D$ value, the mean probability of the simulation model generating daily cash inflows following the theoretical distribution is about 87.90 percent at 1 percent significant level.

On the other hand, on average the mean calculated $D(0.178)$ of daily cash outflows is much less than the mean critical $D$ value $(0.203)$ at the 99 percent confidence level, and less than the mean critical $D$ value (0.189) at the 95 percent confidence level. However, at the 90 percent confidence level, the mean calculated $D$ is greater than the mean critical $D$ (0.152). The probability that the estimated daily cash outflows, that are randomly generated by the simulation model following LogNormal distribution, is 93.70 percent at 1 percent and 5 percent significant levels.

Also, it can be seen from Table 1 that only one sampled KUD (Sample 9) had the probability $(p)$ less than 50 percent, of a daily cash inflows stream following the LogNormal distribution. This mean that daily cash inflows for this particular sampled KUD, which is generated by the simulation model, is more likely not to be following the assumed LogNormal distribution. The historical data shows that the daily cash inflows of this KUD have less variability over the season with the mean of 144,630.52 and the standard deviation of 22,217.77. As well as being paddy growers, farmers who are members of this particular KUD (Sample 9) are active in hand crafting (i.e., wood craft and hand made fabric/batik). Due to continuous demand for handicrafts from tourists, farmers have continuously purchased materials from the KUD. This results in less fluctuation in the KUD's cash inflows.

\section{The Test of the Quantity of Paddies Harvested Daily}

Three important factors (the intercept, slope and $R$ square) have to be determined from the regression results to test the validity of results of the simulation model's subsystem (sub-simulation model). The mean of the actual quantity of paddies harvested daily, and the mean of the quantity of paddies harvested daily, that is generated by the simulation model for 25, 50 and 100 replications for each sampled KUD. These can be seen clearly in Figure 4 and Table 2. 
Figure 4. The Line Plots of The Quantity of Paddies Harvested Daily of the Sub- Actual System and the Sub-Simulation Model

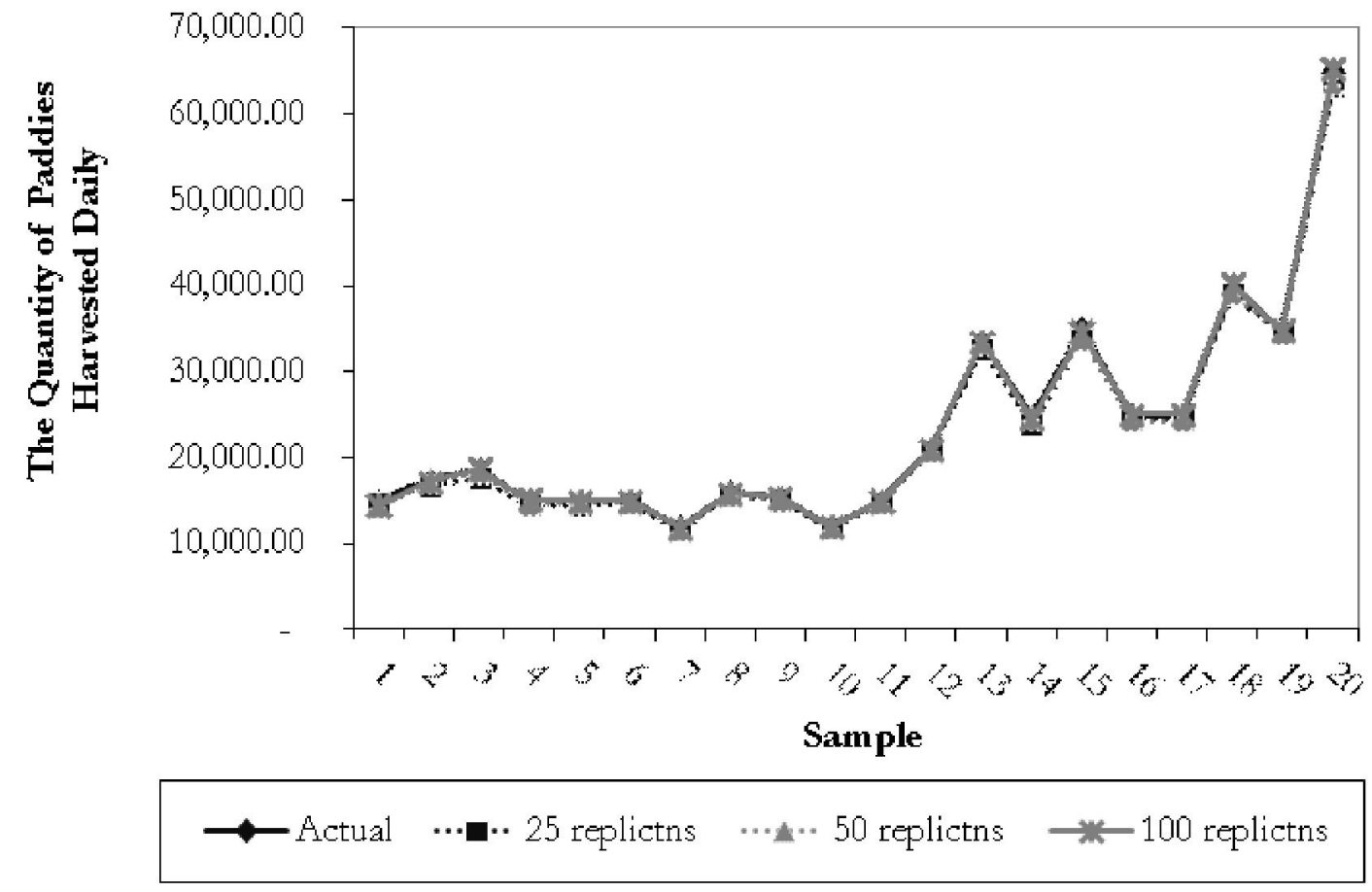

Table 2. The Results of Regression and Correlation Tests of the Quantity of Paddies Harvested Daily of the Sub- Actual System and the Sub-Simulation Model

\begin{tabular}{ccccc}
\hline Replications & Intercept & Slope & $\mathbf{R}^{2}$ & Correlation Coefficient \\
\hline 25 & -72.584 & 0.977 & 0.9996 & 0.9998 \\
50 & 25.263 & 0.9773 & 0.9998 & 0.9999 \\
100 & -168.081 & 1.0052 & 0.9998 & 0.9999 \\
\hline
\end{tabular}

The outputs of the simulation model were analyzed on the basis of two scenarios, the proportion of paddies purchased each day in the range of 25 percent to 100 percent and using a fixed value of 100 percent. For both scenarios, the simulation model was run based on 25, 50 and 100 replications. Although the simulation model allowed for the negative cash balance/availability, the sampled KUDs were not able to purchase the entire paddies expected to be sold by farmers. In Scenario 1 (the range 25 to $100 \%$ of paddies purchased each day), the total quantity of paddies that could be purchased by the KUD ranged from 9.19 percent to 62.07 percent (25 replications), 9.23 percent to 62.67 percent (50 replications) and 9.10 percent to 62.45 percent (100 replications). Meanwhile, the results of Scenario 2 (100\% of paddies purchased each day) indicated that 
8.97 percent to 97.88 percent (25 replications), 9.15 percent to 97.34 percent (50 replications) and 8.93 percent to 97.02 percent (100 replications) of the total quantity of paddies could be purchased by the KUDs. On average, the total quantity of paddies purchased by the KUDs was greater than that of the current practice. Based on the report of the Department of Cooperatives and the finding of research conducted by Ellis (1993b), KUDs were only able to purchase paddies of about 4 percent to 10 percent of the total paddies harvested, which is less than the results of the simulation model. This study identified that the limitations of the paddy storage building, paddy drying floor, and paddy milling machine capacities may contribute to the inability of the KUDs to purchase more paddies from their members. Thus, there are two methods that could be adopted to resolve these limitations. First, the KUDs could borrow at a low interest rate provided by the Indonesian Government to fund their new investment in paddy storage buildings, expanding the paddy drying floor and paddy milling machines. If this approach is chosen, a careful feasibility study needs to be carried out.

Second, the limitations may be removed by renting the facilities owned by private paddy wholesalers or other parties. Although the second approach is cheaper, theoretically this approach is not preferable because this mechanism could lead to collusion between the two parties, the KUDs and private paddy wholesalers, to exploit farmers by buying their produce at the price that is below the floor price. However, this issue is beyond this particular research.

\section{Concluding Remarks}

The results of the Kolmogorov-Smirnov Goodness of Fit tests indicated that on average, based on 0.01 level of significance, the calculated $D$ value $(0.204)$ of daily cash inflow streams was marginally over the critical $D$ value (0.203). If a strict rule is implemented, the assumption of the LogNormal distribution underlying the randomly generated cash inflow stream is not valid. This condition resulted from the calculated $D$ value of one sampled KUD being very high and the probability of the cash inflow stream following the assumed distribution was lower than 0.5. After tracing back the historical data, it was found that this KUD had less variance on its daily cash inflow stream due to routine transactions of selling materials for handcrafts.

Based on the Kolmogorov-Smirnov Goodness of Fit tests, the LogNormal distribution assumption underlying the generation of daily cash outflow, general cost, other cost and paddy milling machine repair cost streams was valid as indicated by their calculated $D$ values being lower than those of the critical $D$ values. Therefore, in general, the assumptions employed in generating daily cash inflow and outflow, general cost, other cost and paddy milling machine repair cost stream were valid.

The results of regression, correlation and t-tests indicated that the simulation-predicted quantity of paddies harvested each day resembled the real system. This was indicated by the slope of the regression line being close to one, and the $\mathrm{R}$ square and coefficient correlation being nearly one. Although the in- 
tercept of the regression line was greater than zero, the $t$-test result indicated that there was no significant difference between the simulation-predicted quantities of paddies purchased each day and the actual system. Similar techniques were used to indicate that the monthly morning rain frequency and the rice fees generated by the simulation model were valid representatives of those of the actual system. Thus, on the basis of the results of these tests, the valid sub-models of the simulation model may contribute to the valid simulation model as a whole.

The results of confidence interval analysis indicated that several KUDs required additional borrowings, and other KUDs might need to reduce their borrowing. The shifting from Scenario 1 to Scenario 2 was only significant to increase the earnings before tax (EBT) for the KUDs that were not constrained by the limitations of their paddy storage building, paddy-drying floor and paddy milling machine capacities.

Although the simulation model is powerful enough as a decision support tool for the management of KUDs, it should not be used by management to predict the paddy yield, but it should be used cautiously to assist them to determine the amount of cash required for purchasing paddies based on various scenarios.

\section{References}

Bassett, G. 1992. Operation Management for Service Industries: Competing in the Service Era (Vol. 261). Westport, Connecticut: Quorum Books.

Baumol, W. J. 1952. The transactions demand for cash: an inventory theoretic approach. Quarterly Journal of Economics LXVI (1):545 - 556.

Bergh, W-M. Van Den, and Hallerbach. 1991. A stochastic cash model with deterministic elements. Paper read at Modelling for Financial Decisions, 20-21 April 1989, at Catania.

Boonma, C.. 1988. Measures for the improvement of agricultural financing for small farmers in Thailand. Paper read at Improved Agricultural Credit for Small Farms in Asia, 12-16 April, at Korea.

Calvert, C. 1995. Delphi Programming Unleashed. Indianapolis: SAMS Publishing.

Chand, S. and Th. Morton. 1982. A perfect planning horizon procedure for a deterministic cash balance problem. Management Science 28 (6): 652 - 669.

Chen, H-H. 1988. Measures for the improvement of agricultural financing for small farmers in Taiwan. Paper read at Improved Agricultural Credit for Small Farms in Asia, 12 - 16 April, at Korea.

Cohen, K. J., and R. M. Cyert. 1961. Computer models in dynamic economics. The Quarterly Journal of Economics LXXV: 112 - 127.

Constantinides, G. M. 1976. Stochastic cash management with mixed and proportional transaction costs. Management Science 22 (12): 1320 - 1331.

Demetrakakes, P., 1998. Farmer's market. Food Processing 59 (8): 20 - 24.

Dillon, H. S. 1992. The Indonesian strategy in the field of agriculture. The Indonesian Quarterly XX (4): 438446. 
Fukui, J., and Y. Hirose. 1993. Poor harvest a natural disaster, but rice shortage is man-made. Tokyo Business Today (December): 28-32.

Golub, B., M. Holmer, R. McKendall, L. Pohlman, and S. A. Zenios. 1995. A stochastic programming model for money management. European Journal of Operational Research 85: 282-296.

Greenberg, I. 1996. At Sara Lee company, Delphi 2.0 delivers a knockout punch. Infoworld 18 (12): 75.

Harijono, T. 1998. Derita petani Jabar belum Berakhir [The Farmers' Suffering in Western Java Was Not Ended Yet]. Kompas (3 February).

Homonoff, R., and D. W. Mullins, Jr. 1975. Cash Management: An Inventory Control Limit Approach. Lexington: Lexington Books.

Ida, L.. 1996. Opini: mengembangkan koperasi: Antara pengusaha besar dan intervensi pemerintah [Opinion: Developing Cooperatives: Between Big Companies and the Government Intervention]. Republika (12 July).

International Monetary Funds (IMF). 1998. Mitigating the social costs of the Asian crisis. Finance and Development (September): 18 - 21.

Johnson, S. P., and K. R. Crawford. 1993. Cash management in rural America. Journal of Cash Management (Jan/Feb): 26-32.

Jones, C. 1995. Rice price stabilisation in Indonesia: An economic assessment of the changes in risk bearing. Bulletin of Indonesia Economic Studies 31 (1): 109 - 128.

Kim, Y-C. 1988. Small farm credit program and agricultural development in Korea. Paper read at Improved Agricultural Credit for Small Farms in Asia, at Korea.

Kleijnen, J. P. C., and W. Van Groenendaal. 1992. Simulation: A Statistical Perspective. Chichester: John Wiley \& Sons.

Kleijnen, J. P. C. 1995a. Statistical validation of simulation models. European Journal of Operational Research 87 (1): 21-34.

Kleijnen, J. P. C. 1995b. Verification and validation of simulation models. European Journal of Operational Research 82 (1): 145-162.

Knepell, P. L., and D. C. Arangno. 1993. Simulation Validation: A Confidence Assessment Methodology. Los Alamitos: IEEE Computer Society Press.

Knoeber, C. R. 1997. Explaining state bans on corporate farming. Economic Enquiry XXXV (January): 151 $-166$.

Krisnamurthi, B. 1996. Opini: Koperasi pedesaan dalam kondisi yang berubah [Opinion: The Village Cooperatives in the Changing Condition]. Republike (12 July).

Kroeker, C. J. 1996. The cooperative movement in Nicaragua: Empowerment and accompaniment of severely disadvantaged peasants. Journal of Social Issues 52 (1): 123 - 138.

Kumar, B. L. 1990. Gambhira co-operative farming society: A successful experiment in collective efforts. Indian Journal of Agricultural Economics 45 (3): 362-366.

Langdon, I. A. 1991. Role of Co-Operatives in Promoting Agricultural Production. Queensland: Gold Coast University College of Graffith University.

Langdon, I. A. 1994. External equity need not compromise farmer control or co-operative principles. Paper read at The IDF Congress Melbourne, at Melbourne. 
Law, A. M., and W. D. Kelton. 1991. Simulation Modeling and Analysis. New York: McGraw-Hill, Inc.

Levy, A., M. Justman, and E. Hochman. 1989. The implication of financial cooperative in Israel's semicooperative village. Journal of Development Economics 30: 25-46.

Madura, J. 1987. Improving cash management with simulation. Journal of Cash Management (Jan./Feb.): 47 $-48$.

Mensching, J., S. Garstka, and T. Morton. 1978. Protective planning-horizon procedures for a deterministic cash balance problem. Operation Research 26 (4): 637 - 652.

Miller, M. H., and D. Orr. 1966. A model of the demand for money by firns. Quarterly Journal of Economics LXXX: 413 - 435.

Neave, E. H. 1970. The stochastic cash balance with mixed costs for increase and decrease. Management Science 16 (7): 472 - 490.

Oehler, S.. 1996. Largest U.S. AG co-op markets to and for producers. Agri Marketing 34 (6): H - M.

Pacheco, X., and S. Teixeira. 1995. Delphi Developer's Guide. Indianapolis: SAMS Publishing.

Pambudy, N. M. 1998b. Sektor pangan, andalan yang nyaris salah urus [The Food Crop Sector, the mainstay that was almost missed managing]. Kompas 21 (December).

Pambudy, N. M. 1998c. Sektor pertanian sebagai penyelamat [The agriculture sector is as a rescuer].Kompas 18 (May).

Paul, R. J., and D. W. Balmer. 1993. Simulation Modelling. Lund: Chartwell-Bratt.

Pidd, M. 1993. Computer Simulation in Management Science. Chichester. John Wiley \& Sons.

Pusat Penelitian dan Pengembangan Pedesaan [P3P], [The Center of Research and Rural Development]. 1997. Kaji Tindak Pengembangan Koperasi Mandiri Inti Dalam Wilayah Pertumbuban Agribisnis di Propinsi Nusa Tenggara Barat [The Follow-up Action of Developing the Self-financing Cooperatives within the Agribusiness Growth Areas in the West Nusa Tenggara Province]. Mataram: Universitas Mataram.

Ramli, A. R. 1988. Measures or schemes for the improvement of agricultural financing for small farmers. Paper read at Improved Agricultural Credit for Small Farms in Asia, 12 - 16 April, at Korea.

Rasmussen, A. E. 1983. Financial Management in Co-operative Enterprises. Saskatchewan: Co-operative College of Canada.

SAH., NAL., MAR., and SUP. 1999. Pembelian gabah di Sumatera kacau [The purchase of paddies in Sumatera was not well managed]. Kompas 3 (March).

Santoso, B. 1993. Budget variance and working capital analyses of the provision of fertilizers and pesticides, and the purchase of rice by agricultural cooperatives [The KUDs]: A case study of the West Lombok regency. Master Thesis. The School of Accounting, The Faculty of Business and Management, University of South Australia, Adelaide.

Sidhu, J. S., and R. S. Sidhu. 1990. Case studies of successful and unsuccessful primary co-operative service society and milk producers co-operative society in Punjab. Indian Journal of Agricultural Economics 45 (3): 367-373.

Stone, B. K., and T. W. Miller. 1987. Daily cash forecasting with multiplicative models of cash flow patterns. Financial Management (Winter): 45 - 65.

Suganda, H., 1998. Petani hanya kebagian "daki" [Farmers only got "grime”]. Kompas 18 (May).

Suyanto, B. 1996. HDG, KUD, dan hegemoni tengkulak [The paddy floor price, KUDs and hegemony of paddy brokers]. Republika 5 (March). 
Gadjah Mada International Journal of Business - January-April, Vol. 14,No. 1, 2012

Taber, C. S., and R. J. Timpone. 1996. Computational Modeling. Thousand Oaks: Sage Publications.

Thompson, R. 1986. Understanding cash flow: A system dynamics analysis. Journal of Small Business Management 24 (2): 23 - 30.

Timmer, C. P. 1996. Does BULOG stabilise rice prices in Indonesia? Should it try? Bulletin of Indonesian Economic Studies 32 (2): 45 - 74.

Timmer, C. P. 1997. Building efficiency in agricultural marketing: The long-run role of BULOG in the Indonesian food economy. Journal of International Development 9 (1): 133 - 145.

Tobin, J. 1956. The interest-elasticity of transactions demand for cash. The Review of Economics and Statistics XXXVIII (3): 214 - 247.

World Bank. 1998a. Indonesia at a Glance. New York: The World Bank.

World Bank. 1998b. World Development Indicators 1998 CD-ROM. New York: The World Bank.

Wozniewicz, A. J., N. Shammas, and T. Campbell. 1995. Teach Yourself Delphi in 21 Days. Indianapolis: SAMS Publishing.

YAS. 1998. Krisis moneter ciptakan peluang agrobisnis [The Indonesian economic crisis created an opportunity for agribusiness]. Kompas 2 (February).

Zaman, M. 1992. Working Capital Management Model for Public Enterprise: A Case Study of Bangladesh. MacArthur: University of Western Sydney. 
